\title{
INFLUENCE OF POCKET GOPHER MOUNDS ON NONNATIVE PLANT ESTABLISHMENT IN A SHRUBSTEPPE ECOSYSTEM
}

\author{
G. Page Kyle ${ }^{1}$, Andrew Kulmatiski ${ }^{1}$, and Karen H. Beard ${ }^{1,2}$
}

\begin{abstract}
Soil disturbances across a wide range of spatial scales have been found to promote the establishment of invasive plant species. This study addresses whether mounds built by northern pocket gophers (Thomomys talpoides) in the shrubsteppe environment of north central Washington are facilitating plant invasions into native-dominated fields. Research was conducted in native-dominated plant communities adjacent to ex-arable, nonnative-dominated fields. To determine the effect of mounds on plant growth, we recorded new establishment and persistence of all plant species over 2 growing seasons on 10-19 mound and intermound areas in 10 fields. Nonnative plant establishment was not affected by mounds, but native plant establishment, particularly of the dominant native Pseudoroegneria spicata was lower on mounds than on intermounds. Early in the growing season, mounds had reduced soil moisture, bulk density, soil strength, $\mathrm{N}$ mineralization rates, and total $\mathrm{N}$ and $\mathrm{C}$ concentrations, and similar extractable $\mathrm{NO}_{3}{ }^{-}$concentrations relative to intermound soils. Our results did not suggest that soil disturbance improved nonnative growth resulting in competitive suppression of natives; rather, our results suggested that low soil moisture and slow $\mathrm{N}$ mineralization rates on mounds in this ecosystem present relatively stressful conditions for native plant growth.
\end{abstract}

Key words: Thomomys talpoides, pocket gophers, nonnative plant invasion, soil disturbance, shrubsteppe, Washington.

Nonnative plant species can form stable plant communities in previously agricultural shrubsteppe lands throughout western North America, while surrounding undisturbed lands remain relatively uninvaded (Rickard and Vaughan 1988, Kulmatiski 2006). Plant invasions following large-scale mechanical soil tillage are well documented (e.g., Elton 1958, Hobbs and Huenneke 1992), but uncultivated lands may also be subjected to smaller-scale natural mechanical disturbances, which may similarly play a role in nonnative species establishment. Soil tailings of mound-building fossorial rodents, for example, can cover up to $30 \%$ of the soil surface each year (Hobbs and Mooney 1991) and have been demonstrated to enhance invasive plant establishment in a variety of ecosystem types (reviewed in D'Antonio et al. 1999).

Rodent mounds are typically colonized by nondominant species in plant communities, usually forbs and annuals (Goldberg and Gross 1988, Huntly and Inouye 1988, Martinsen et al. 1990). While this is generally true for plant establishment in canopy gaps (Grubb 1977, Gross 1987), establishment on rodent mounds may also be influenced by properties of mound soils, which differ from those of the surround- ing soils (reviewed in Reichman and Seabloom 2002). Relative to "intermound" soils, gopher mounds typically have higher maximum daytime temperatures, reduced bulk density, and lower total carbon $(\mathrm{C})$ and nitrogen $(\mathrm{N})$ pools (Litaor et al. 1996, Sherrod and Seastedt 2001, Reichman and Seabloom 2002, Canals et al. 2003). Sherrod and Seastedt (2001) found mound soils to have lower C:N than surrounding soils, and lower soil moisture has also been reported (Simkin et al. 2004). Soil moisture is known to influence establishment on mounds (Grant et al. 1980); in general, mounds at relatively mesic sites have faster revegetation rates than mounds at xeric sites (Goldberg and Gross 1988, Umbanhowar 1995, Berlow et al. 2002).

Soil moisture and C:N can also play a role in regulating $\mathrm{N}$ availability to plants, as both influence soil N mineralization rates (Stanford and Smith 1972, Paul and Clark 1996). To date, studies have found no significant differences between mound and intermound net $\mathrm{N}$ mineralization rates (Cortinas and Seastedt 1996, Canals et al. 2003, Eviner and Chapin 2005). However, of these studies, none tested $\mathrm{C}: \mathrm{N}$, and 2 tested soil moisture but found no significant mound-intermound differences (Cortinas and Seastedt 1996, Eviner and Chapin

${ }^{1}$ Department of Wildland Resources and the Ecology Center, Utah State University, Logan, UT 84322-5230.

${ }^{2}$ Corresponding author. E-mail: karen.beard@usu.edu 
2005). Still, mounds have been consistently shown to have high levels of nitrate $\left(\mathrm{NO}_{3}^{-}\right.$; Litaor et al. 1996, Sherrod and Seastedt 2001, Canals et al. 2003). Because N availability can promote nonnative establishment (Burke and Grime 1996, Brooks 2003), high N concentrations or $\mathrm{N}$ mineralization rates may be important for nonnative plant establishment on rodent mounds.

In shrubsteppe fields in the Methow Valley, Washington, up to $20 \%(\bar{x}=3.4 \%$, range 0\%-20\%; A. Kulmatiski unpublished data) of the surface of otherwise undisturbed fields consists of soil tailings from the burrows of the northern pocket gopher, a native rodent (Geomyidae: Thomomys talpoides). Across the landscape, there are a number of abandoned agricultural fields that are presently occupied by persistent nonnative plant communities (Kulmatiski 2006). While subsequent spread of these nonnatives into surrounding native plant communities has been minimal (Kulmatiski 2006), the process may be expedited by soil disturbances, such as mounds built by pocket gophers. For appropriate management, it is important to know whether pocket gopher mounds act as microsites allowing invasion into native communities.

Little research on the ecosystem impacts of pocket gophers has been conducted in shrubsteppe, and the physical effects of gophermound building on soils are known to vary by ecosystem (Cortinas and Seastedt 1996), probably depending on climate and on soil organic matter content, texture, and water content (Sojka 1999). Our primary objective was to determine whether gopher mounds facilitate nonnative plant establishment in native-dominated communities. To do this, we measured establishment of new plants and persistence of existing plants over 2 growing seasons on gopher mounds and on unvegetated intermound soils in 10 fields, each adjacent to an abandoned agricultural field. To assess the role of pocket gophers on soil properties compared to past studies, we also measured soil physical characteristics, nutrient concentrations, and $\mathrm{N}$ mineralization rates on mounds and on surrounding intermound soils.

\section{Study Site}

This study was conducted in the shrubsteppe of the Methow Valley, Washington $\left(48^{\circ} 37^{\prime} \mathrm{N}\right.$, $107^{\circ} 10^{\prime} \mathrm{W}, 550-750 \mathrm{~m}$ asl). Aerial photographs and ground-truthing allowed identification of nonagricultural areas adjacent to abandoned agricultural fields on land managed by the Washington Department of Fish and Wildlife. Nonagricultural areas were dominated by native species but were located near potential source populations of nonnatives in abandoned agricultural fields (Kulmatiski 2006). Native vegetation consisted of grasses, forbs, and shrubs, primarily Pseudoroegneria spicata (Pursh.), Balsamorhiza sagittata (Pursh.), Purshia tridentata (Pursh.), Artemisia tridentata (Nutt.), Lupinus arbustus (Dougl. ex Lindl.), L. aridus (Dougl.), and L. caudatus (Kellogg). Nonnative plant species in the study system consisted primarily of Centaurea diffusa (Lam.), Bromus tectorum (L.), Poa bulbosa (L.), Cardaria draba (L.), Sisymbrium altissimum (L.) and S. loeselii (L.). In nonagricultural areas, native plants covered $43 \% \pm 2 \%$ (absolute cover; $\bar{x} \pm s$ ) of the ground while nonnative plants covered $3 \%$ $\pm 1 \%$ of the ground (Kulmatiski 2006); thus, approximately $54 \%$ was bare ground. In abandoned agricultural fields, nonnative plants covered $38 \% \pm 3 \%$ of the ground while native plants covered $4 \% \pm 1 \%$ of the ground (Kulmatiski 2006); thus, approximately $58 \%$ was bare ground. Soils are in the Newbon-Conconully association: coarse-loamy mixed mesic Typic Haploxerolls (Lenfesty 1980). Mean annual rainfall is $380 \mathrm{~mm}$, with $67 \%$ falling between October and March (NCDC 2004). The growing season begins with snowmelt in March or April and continues until snowfall in November, though most grasses and forbs undergo seasonal senescence by July.

\section{Methods}

\section{Plant Establishment Survey}

In June 2003, 10 native-dominated fields that had never been cultivated were randomly selected from 25 possible sites. Each field was within $100 \mathrm{~m}$ of an abandoned agricultural field (a potential seed source of nonnative species) and each had $>5 \%$ of the surface covered by gopher mounds. In a $25 \times 25$-m area within each field, all recently formed gopher mounds were located (10-19 in each field), and a square $100-\mathrm{cm}^{2}$ microplot was placed on the center of each mound. An intermound microplot of the same size was placed on the nearest area to each mound with no mature perennial plants on a random compass direction 
(maximum distance between paired microplots: $80 \mathrm{~cm}$ ). All stems of all plants present in each mound and intermound microplot were identified by species and counted.

In June 2004, all stems in each microplot were counted again. New establishment by species in each microplot was calculated as the number of stems present in 2004 minus those present in 2003; values $<0$ were considered to be 0 . Persistence was defined as presence of a species in 2004 in a microplot where the species had been present in 2003. To compare new establishment to the surrounding plant canopy, plant species composition in the surrounding area was estimated. A $1-\mathrm{m}^{2}$ plot was placed over each mound, and percent cover of all plant species was determined by point-intercept estimation with 16 points (NARSC 1996). Because of the scarcity of vegetation on mounds even after 1 year of vegetative regrowth, percent cover estimates were corrected to account for the area of the mound within each $1-\mathrm{m}^{2}$ plot.

Prior to statistical analysis, data on new establishment and persistence of existing plants from individual mound and intermound microplots were averaged by field. Mixed linear models (SAS Institute, Inc. 2004) with fields as random effects were used to compare estimates of mound and intermound establishment of the 5 most commonly occurring native species, the 3 most common nonnative species, native species and nonnative species as groups, and total stem count. Species were considered nonnative if listed as "introduced" in Whitson et al. (1999). Mixed logistic regressions (PROC GLIMMIX; SAS Institute, Inc. 2005) with fields as random effects were used to compare the likelihood of mound versus intermound persistence of these species and groupings in each field between 2003 and 2004.

\section{Soil Survey}

Five mound-intermound pairs were selected from randomly located plots in 10 native-dominated fields that had been randomly selected from 25 possible fields ( 3 of the fields were also used in the plant establishment survey). Gravimetric soil moisture was measured on each mound and the corresponding adjacent intermound area in March, April, June, and July 2004 (Jarrell et al. 1999). Mound soil cores were taken to the depth of the mound (mean height $10 \mathrm{~cm}$ ), and intermound cores were taken to $10 \mathrm{~cm}$. In these same plots, $\mathrm{N}$ mineralization rates in mound and intermound soils were determined using field incubation (Robertson et al. 1999). In March 2004, two soil cores were taken at each mound or intermound area. The 1st was taken for immediate extraction of inorganic $\mathrm{N}$, and the 2nd was placed in an unsealed plastic bag and returned to the soil core hole to remain there for 4 weeks. This technique allowed air flow to the soil, but limited plant uptake of $\mathrm{N}$ in the soil, allowing for a quantitative measure of plant-available $\mathrm{N}$ produced between the 2 sampling times. Fifteen samples directly affected by gophers during this incubation period were discarded. Inorganic $\mathrm{N}$ was extracted using a $2: 1$ soil to $2 \mathrm{M} \mathrm{KCl}$ ratio by mass. Extractants were analyzed for ammonium $\left(\mathrm{NH}_{4}{ }^{+}\right)$and nitrate $\left(\mathrm{NO}_{3}{ }^{-}\right)$concentrations on a Lachat Quickchem 8000 flow injection analyzer (Lachat Instruments, Loveland, CO).

Mound and intermound soil bulk density, penetration resistance, and shear strength were measured at each sampling location. Penetration resistance and shear strength were recorded as the means of 2 measurements made with a handheld penetrometer and a Torvane shear device, respectively (Durham Geo Slope Indicator, Stone Mountain, GA). Finally, soil samples from 30 mound-intermound pairs randomly assigned throughout the fields from the vegetation survey ( 3 per field) were collected, air-dried, sieved to $<2$ $\mathrm{mm}$, and analyzed for total $\mathrm{C}$ and $\mathrm{N}$ by dry combustion on a LECO Truspec CN (LECO Corporation, St. Joseph, MI; Sollins et al. 1999).

Soil moisture was compared between mounds and intermound areas at each sampling time, using single-factor ANOVA. Single-factor ANOVA was also used to test for mound and intermound differences in soil properties: net $\mathrm{N}$ mineralization rates, bulk density, penetration resistance and shear strength, and concentrations of $\mathrm{C}, \mathrm{N}$, and $\mathrm{NO}_{3}{ }^{-}$. In all analyses, significant differences were determined at $P<0.05$.

\section{RESUlTS}

Relative to intermound areas, mounds had low establishment of the most abundant native bunchgrass, Pseudoroegneria spicata (Table 1), which accounted for $49 \%$ of the total vegetation cover in the fields surveyed. Establishment 
TABLE 1. Mean $\left( \pm s_{\bar{x}}\right)$ new plant establishment between 2003 and 2004 on mounds and intermound areas in 10 fields, Methow Valley, Washington. We used mixed linear models to test mound and intermound establishment.

\begin{tabular}{|c|c|c|c|c|}
\hline & $\begin{array}{l}\text { Mound } \\
\left(\bar{x} \pm s_{\bar{x}}\right)\end{array}$ & $\begin{array}{l}\text { Intermound } \\
\qquad\left(\bar{x} \pm s_{\bar{x}}\right)\end{array}$ & $F_{(1,9)}$ & $P$ \\
\hline Native species & $1.78 \pm 0.29$ & $2.20 \pm 0.44$ & 2.37 & 0.16 \\
\hline Calochortus elegans & $0.09 \pm 0.04$ & $0.22 \pm 0.11$ & 2.73 & 0.13 \\
\hline Collinsea linearis & $0.37 \pm 0.13$ & $0.34 \pm 0.15$ & 0.00 & 0.95 \\
\hline Crepis atribarba & $0.08 \pm 0.07$ & $0.08 \pm 0.04$ & 0.02 & 0.89 \\
\hline Polygonum douglasii & $0.17 \pm 0.03$ & $0.16 \pm 0.05$ & 0.07 & 0.80 \\
\hline Pseudoroegneria spicata & $0.04 \pm 0.03$ & $0.27 \pm 0.08$ & 8.85 & 0.016 \\
\hline Exotic species & $0.64 \pm 0.24$ & $0.67 \pm 0.31$ & 0.11 & 0.75 \\
\hline Bromus tectorum & $0.33 \pm 0.14$ & $0.18 \pm 0.09$ & 2.05 & 0.19 \\
\hline Poa bulbosa & $0.16 \pm 0.08$ & $0.40 \pm 0.19$ & 2.40 & 0.16 \\
\hline Sisymbrium spp. & $0.08 \pm 0.07$ & $0.03 \pm 0.03$ & 0.78 & 0.40 \\
\hline All species & $2.41 \pm 0.51$ & $2.87 \pm 0.59$ & 4.00 & 0.08 \\
\hline
\end{tabular}

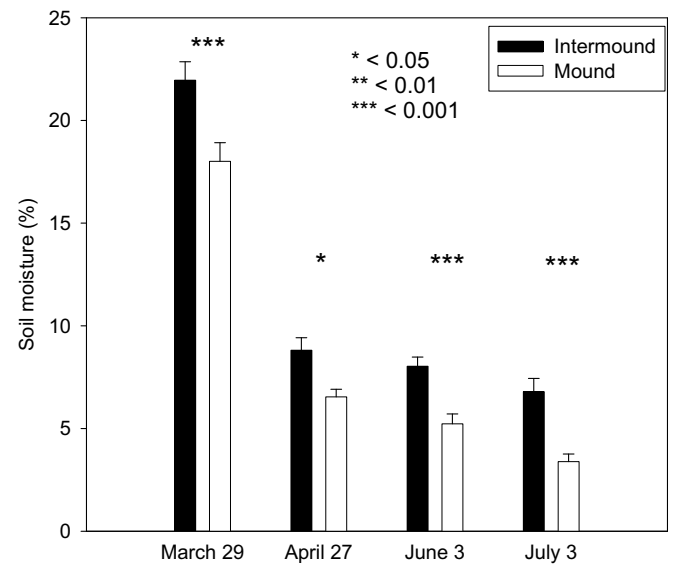

Fig. 1. Mean mound and intermound gravimetric soil moisture at 4 sampling times between March and July 2004, measured in 10 fields in Methow Valley, Washington. Bars represent 1 standard error. Significant differences within each sampling time were determined by mixedmodel ANOVA with mound-intermound pairs treated as random effects.

of no other species or group was influenced on mounds relative to intermound areas. During the 2 years of the study, persistence of $P$. spicata was also lower on mounds than on intermound areas $(F=8.08, P=0.019)$.

No nonnative species had significantly different rates of new establishment on mounds relative to intermound areas (Table 1). Mean establishment of B. tectorum was $82 \%$ greater on mounds than on intermound areas (not significant), but Poa bulbosa establishment was $150 \%$ greater on intermound areas than on mounds (not significant). In aggregate, nonnative establishment was $5 \%$ greater on intermound areas than on mounds (not significant).
Given our sample sizes and standard deviations, we could have detected significant differences of $200 \%$ between treatment levels for B. tectorum, and $135 \%$ between treatment levels for $P$. bulbosa. The sample sizes necessary to detect differences given our measured differences were 18 and 33, respectively. Nonnative species accounted for $26 \%$ of total plant establishment on mounds and $23 \%$ of total plant establishment in intermound areas (not significant). Establishment of native species was significantly greater than that of nonnative species on mounds $\left(F_{1,9}=52.6, P<0.001\right)$ and in intermound areas $\left(F_{1,9}=10.3 ; P=0.011\right.$; Table 1).

Most measured soil characteristics differed between mounds and intermound areas. At all 4 sampling times, mound soil moisture was lower than intermound soil moisture $(P<$ 0.001; Fig. 1). Net $\mathrm{N}$ mineralization in the 1st month of the growing season was $0.17 \mathrm{mg}$. $\mathrm{kg}^{-1} \mathrm{day}^{-1}$ on mound soils, $35 \%$ lower than on intermound soils, where it was $0.27 \mathrm{mg}$. $\mathrm{kg}^{-1}$ day $^{-1}\left(F_{1,32}=14.8, P<0.001\right.$; Fig. 2). $\mathrm{NO}_{3}{ }^{-}$concentrations measured in March 2004 did not differ between mound and intermound soils (Table 2).

Penetration resistance, shear strength, and bulk density were lower for mound soils than for intermound soils by $80 \%, 76 \%$, and $7.5 \%$ (Table 2), respectively. Two mound samples had abnormally high $\mathrm{C}$ and $\mathrm{N}$, probably because of decomposing organic matter in the samples (e.g., May and Webber 1982); these were identified as outliers by Grubbs's test (Grubbs 1950 ) and removed from analysis. C and $\mathrm{N}$ were each lower in mound soils than in intermound soils by $19 \%$ and $24 \%$, respectively, and C:N was higher for mound soils (Table 2). 
TABLE 2. Soil physical characteristics on mounds compared to intermound areas; Methow Valley, Washington. Significant differences were determined by Tukey adjusted least-squares means with mound-intermound pairs treated as random effects. For each test, numerator $\mathrm{df}=1$.

\begin{tabular}{lccccr}
\hline & $\begin{array}{c}\text { Mound } \\
\left(\bar{x} \pm s_{\bar{x}}\right)\end{array}$ & $\begin{array}{c}\text { Intermound } \\
\left(\bar{x} \pm s_{\bar{x}}\right)\end{array}$ & $F$ & df & $P$ \\
\hline Bulk density $\left(\mathrm{g} \cdot \mathrm{cm}^{-3}\right)$ & $0.98 \pm 0.03$ & $1.07 \pm 0.03$ & 6.99 & 32 & 0.019 \\
Penetration resistance $\left(\mathrm{kg} \cdot \mathrm{cm}^{-2}\right)$ & $0.5 \pm 0.1$ & $2.6 \pm 0.2$ & 360 & 40 & $<0.001$ \\
Shear strength $\left(\mathrm{kg} \cdot \mathrm{cm}^{-2}\right)$ & $0.6 \pm 0.0$ & $2.6 \pm 0.1$ & 435 & 40 & $<0.001$ \\
$\mathrm{C}\left(\mathrm{g} \cdot \mathrm{kg}^{-1}\right)$ & $20.7 \pm 1.3$ & $25.7 \pm 1.6$ & 6.01 & 27 & 0.021 \\
$\mathrm{~N}\left(\mathrm{~g} \cdot \mathrm{kg}^{-1}\right)$ & $1.2 \pm 0.1$ & $1.6 \pm 0.1$ & 7.51 & 27 & 0.011 \\
$\mathrm{C}: \mathrm{N}$ & $17.3 \pm 0.4$ & $16.1 \pm 0.2$ & 9.06 & 25 & 0.006 \\
$\mathrm{NO}_{3}-\left(\mathrm{mg} \cdot \mathrm{kg}^{-1}\right)$ & $1.95 \pm 0.31$ & $1.85 \pm 0.26$ & 0.07 & 49 & 0.79 \\
\hline
\end{tabular}

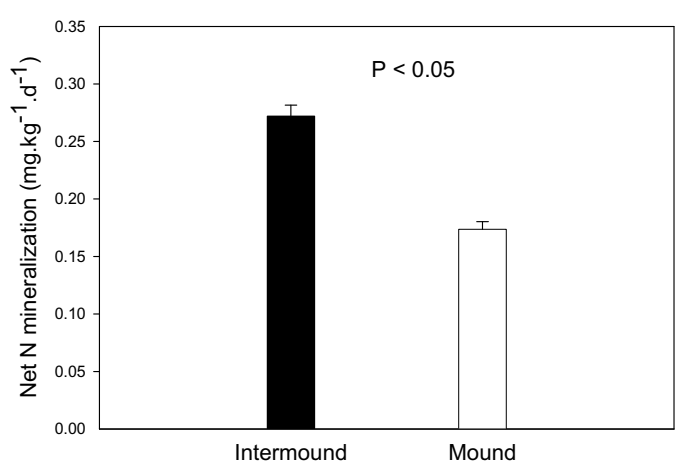

Fig. 2. Mean mound and intermound N mineralization rates measured in 10 fields in Methow Valley, Washington. Bars represent 1 standard error. Significant differences were determined by single-factor ANOVA.

\section{Discussion}

Mounds decreased establishment and persistence of the dominant native perennial bunchgrass, P. spicata, which accounted for the majority of the plant cover in the fields sampled. By decreasing the abundance of $P$. spicata, gopher mounds increased the proportional abundance of the less dominant species in the plant canopy, a finding that is generally supportive of observations in different ecosystems (Platt 1975, Goldberg and Gross 1988, Martinsen et al. 1990). Absolute nonnative establishment, however, was not enhanced on mounds relative to intermound areas.

Studies finding that mounds (rodent-created and simulated) promote invasive species have generally reported plant establishment to be between 3 and 10 times greater on mounds than on surrounding soils (Hobbs and Mooney 1985, Peart 1989, Bossard 1991, Hunter 1991, D’Antonio 1993, McEvoy and Rudd 1993). In this study, however, no mound- intermound differences were detected for establishment of nonnative species, individually or as a group. Mean establishment of $B$. tectorum, the nonnative species that showed the most positive response to mounds, was $80 \%$ greater on mounds than on intermound areas, but this difference was not significant. Our sampling design allowed us to detect differences of $200 \%$ for this species, so differences of the magnitude reported in the literature did not occur. While a larger sample size may have detected significant differences among our observed treatment means for B. tectorum and $P$. bulbosa, this does not apply to nonnative species as a group (minimum $N>3000$ ).

Gopher mounds do play a role in the process of nonnative invasion by creating plant-free space and suppressing the establishment of native species. However, mounds only accounted for $14 \%$ of all bare, unvegetated soil in 25 nonagricultural fields in the study system (A. Kulmatiski unpublished data). Plant interspaces are a typical part of the vegetation mosaic in semiarid ecosystems (Schultz 1995), and are thought to be an aboveground reflection of allocation of resources by plants into development of extensive root systems (Noy-Meir 1985, Schultz 1995). Plant interspaces do not appear to be old, uncolonized mounds because there is no correlation between percent cover of unvegetated soils and mound cover (A. Kulmatiski unpublished data).

Studies have suggested that vegetation differences typically observed on mounds relative to surrounding soils may be explained, in part, by altered nutrient availability on mounds (Spencer et al. 1985, Reichman et al. 1993). It has been reported that despite having low total $\mathrm{C}$ and $\mathrm{N}$ pools, mounds often have elevated $\mathrm{NO}_{3}{ }^{-}$levels (Litaor et al. 1996, Sherrod and Seastedt 2001, Canals et al. 2003). These 
high $\mathrm{NO}_{3}{ }^{-}$concentrations likely reflect decreased root activity in mounds and are also expected to improve growth of ruderal species, which require large $\mathrm{N}$ concentrations to maintain rapid growth rates. However, in this study, while $\mathrm{C}$ and $\mathrm{N}$ concentrations were lower on mounds than on intermounds, $\mathrm{NO}_{3}{ }^{-}$concentrations were not elevated on mounds. Moreover, during the growing season, net $\mathrm{N}$ mineralization rates were lower for mound soils than for intermound soils. The slow net $\mathrm{N}$ mineralization rates on mounds may have been slowed by low soil moisture (Fig. 1), which limits microbial mineralization of organic $\mathrm{N}$ (Stanford and Smith 1972).

Because inorganic $\mathrm{N}$ concentrations do not differ between mound and intermound soils and because $\mathrm{N}$ mineralization rates are low in mound soils, mound soils in this ecosystem provide less plant-available $\mathrm{N}$ than intermound soils during the 1st month following snowmelt. This is a critical time for plant establishment and growth in the shrubsteppe, because it is the time of year with the greatest soil moisture (Rickard and Vaughan 1988). Because high $\mathrm{N}$ concentrations generally promote nonnative plant growth (e.g., Burke and Grime 1996), decreased inorganic $\mathrm{N}$ availability may play a role in our finding that nonnative establishment is not increased on mounds.

Relatively low levels of soil moisture also tend to make mounds less hospitable to plant growth. While soil moisture was lower on mounds than on intermound areas at all sampling times, the difference was probably most important in terms of limiting plant growth in the later sampling times (June, July), since during these times the differences observed may have represented the difference between plant-available soil moisture and the wilting point (Kulmatiski et al. 2006a). This general mechanism, that mounds constitute stressful microsites for plant growth, is also supported by data on interannual persistence of standing vegetation on mounds and intermound areas. Several studies report higher plant seedling mortality off mounds than on mounds, as mounds constitute exposed microsites that herbivorous rodents tend to avoid (Klaas et al. 1998, Wolfe-Bellin and Moloney 2000). However, in this study, we found the persistence of already established vegetation to be higher off mounds than on mounds.
Mounds did have reduced soil strength, which, all else equal, would be expected to expedite root growth and facilitate plant establishment (Unger and Kaspar 1994). In fact, soil loosening has been experimentally shown to promote nonnative plant establishment in this study system (Kyle et al. 2007). However, on mounds, the positive effect of soil loosening on plant growth appears to be outweighed by the negative effects of reduced soil moisture and $\mathrm{N}$ availability. Similarly, total plant persistence was lower on mounds than on intermound areas, indicating that mounds constitute stressful microsites for plant growth.

The finding that small-scale soil disturbance does not initiate invasion of nonnative species on native-dominated fields is corroborated by Kulmatiski et al. (2006b), who showed that seeded nonnative species do not establish vigorous populations in hand-tilled $1-\mathrm{m}^{2}$ plots in native-vegetated fields. Moreover, chronosequence data from primarily native fields adjacent to abandoned agricultural fields throughout the study system show that the native communities, most of which do have pocket gopher activity, have resisted nonnative plant invasion for decades (Kulmatiski 2006). These observations suggest that nonnative plant establishment on rodent mounds is driven by different mechanisms than those driving nonnative establishment following tillage; further research may be helpful in isolating these underlying mechanisms.

In conclusion, pocket gopher mounds did not directly facilitate the invasion of nonnative species into native-dominated plant communities, but did suppress native plant establishment. In contrast to ecosystems in which mounds constitute nutrient-rich microsites favorable for plant growth (Litaor et al. 1996, Sherrod and Seastedt 2001, Canals et al. 2003), mound soils in the study system were resource poor. We suggest that low bulk density in gopher mounds increases soil water infiltration rates resulting in low soil moisture and low net $\mathrm{N}$ mineralization rates relative to intermound soils. We suggest that these low resource conditions explain why nonnative plant establishment was not increased on mounds.

\section{ACKNOWLEDGMENTS}

This research was supported by USDANRICGP Biology of Weedy and Invasive Plants 
\#35320-13473; the Utah State Agricultural Experiment Station, Utah State University, Logan, Utah (approved as journal paper no. 7791); and a Presidential Fellowship from the School of Graduate Studies, Utah State University. We thank J. Mountjoy of the Washington Department of Fish and Wildlife (WDFW) for permission to use WDFW field sites, R. Ryel and J. MacMahon for help in designing the study, D. Roberts and S. Durham for assistance with statistical programming, and $\mathrm{M}$. McEntee for assistance in the field.

\section{Literature Cited}

Berlow, E.L., C.M. D’Antonio, and S.A. Reynolds. 2002. Shrub expansion in montane meadows: the interaction of local-scale disturbance and site aridity. Ecological Applications 12:1103-1118.

BossaRD, C.C. 1991. The role of habitat disturbance, seed predation and ant dispersal on the establishment of the exotic shrub Cytisus scoparius (Scotch broom) in California. American Midland Naturalist 126:1-13.

BRoоKs, M.L. 2003. Effects of increased soil nitrogen on the dominance of alien annual plants in the Mojave Desert. Journal of Applied Ecology 40:344-353.

Burke, M.J.W., and J.P. Grime. 1996. An experimental study of plant community invasibility. Ecology 77 : 776-790.

Canals, R.M., D.J. Herman, and M.K. Firestone. 2003. How disturbance by fossorial mammals alters $\mathrm{N}$ cycling in a California annual grassland. Ecology $84: 875-881$.

Cortinas, R.M., and T.R. SEastedt. 1996. Short- and long-term effects of gophers (Thomomys talpoides) on soil organic matter dynamics in alpine tundra. Pedobiologia 40:162-170.

D’Antonio, C.M. 1993. Mechanisms controlling invasion of coastal plant communities by the alien succulent Carpobrotus edulis. Ecology 74:83-95.

D’Antonio, C.M., T.D. Dudley, and M. Mack. 1999. Disturbance and biological invasions: direct effects and feedbacks. Pages 413-452 in L.R. Walker, editor, Ecosystems of the world 16: ecosystems of disturbed ground. Elsevier, New York.

ELton, C.S. 1958. The ecology of invasions by animals and plants. Metheun, London, U.K.

Eviner, V.T., AND F.S. ChapIn. 2005. Selective gopher disturbance influences plant species effects on nitrogen cycling. Oikos 109:154-166.

GoldberG, D.E., AND K.L. Gross. 1988. Disturbance regimes of midsuccessional old fields. Ecology 69: 1677-1688.

Grant, W.E., N.R. French, and L.J. Folse, Jr. 1980. Effects of pocket gopher mounds on plant production in shortgrass prairie ecosystems. Southwestern Naturalist 25:215-224.

Gross, K.L. 1987. Mechanisms of colonization and species persistence in plant communities. Pages 173-188 in W. Jordan, M. Gilpin, and J.D. Aber, editors, Restoration ecology: theory and practice. Cambridge University Press, Cambridge, U.K.
GrubB, P.J. 1977. The maintenance of species richness in plant communities: the importance of the regeneration niche. Biological Reviews of the Cambridge Philosophical Society 52:107-145.

Grubbs, F.E. 1950. Sample criteria for testing outlying observations. Annals of Mathematics and Statistics 21:27-58.

Hobbs, R.J., And L. Huenneke. 1992. Disturbance, diversity, and invasion: implications for conservation. Conservation Biology 6:324-337.

Hobbs, R.J., and H.A. Mooney. 1985. Community and population dynamics of serpentine grassland annuals in relation to gopher disturbance. Oecologia 67:342351.

. 1991. Effects of rainfall variability and pocket gopher disturbance on serpentine annual grassland dynamics. Ecology 72:59-68.

Hunter, R. 1991. Bromus invasions on the Nevada test site: present status of B. rubens and B. tectorum with notes on their relationship to disturbance and altitude. Great Basin Naturalist 51:176-182.

Huntly, N., AND R. InOuYe. 1988. Pocket gophers in ecosystems: patterns and mechanisms. BioScience 38:786-793.

Jarrell, W.M., D.E. Armstrong, D.F. Grigal, E.F. Kelly, H.C. Monger, And D.A. Wedin. 1999. Soil water and temperature status. Pages 55-73 in G.P. Robertson, D.C. Coleman, C.S. Bledsoe, and P. Sollins, editors, Standard soil methods for long-term ecological research. Oxford University Press, New York.

Klaas, B.A., B.J. Danielson, and K.A. Moloney. 1998. Influence of pocket gophers on meadow voles in a tallgrass prairie. Journal of Mammalogy 79:942-952.

Kulmatiski, A. 2006. Exotic plants establish persistent communities. Plant Ecology 187:261-275.

Kulmatiski, A., K.H. Beard, and J.M. Stark. 2006a. Water-use patterns in semi-arid native and exotic communities. Plant and Soil 288:271-284.

. 2006b. Soil history as a primary control on plant invasion in abandoned agricultural fields. Journal of Applied Ecology 43:868-876.

Kyle, G.P., K.H. Beard, and A. Kulmatiski. 2007. Reduced soil compaction enhances establishment of non-native plant species. Plant Ecology 193:223-232.

Lenfesty, C.D. 1980. Soil survey of Okanogan County area, Washington. USDA Soil Conservation Service, Washington State University. AGRIS record number US8039204. 153 pp.

Litaor, M.I., R. Mancinelli, and J.C. HaLfPenny. 1996. The influence of pocket gophers on the status of nutrients in alpine soils. Geoderma 70:37-48.

Martinsen, G., J. Cushman, and T. Whitham. 1990. Impact of pocket gopher disturbance on plant species diversity in a shortgrass prairie community. Oecologia 83:132-138.

MaY, D.E., AND P.J. Webber. 1982. Spatial and temporal variability of the vegetation and its productivity, Niwot Ridge, CO. Pages 36-62 in J.C. Halfpenny, editor, Ecological studies in the Colorado alpine: a Festschrift for John W. Marr. Institute of Arctic and Alpine Research Occasional Paper No. 37, University of Colorado, Boulder.

McEvor, P.B., AND N.T. RudD. 1993. Effects of vegetation disturbances on insect biological control of tansy ragwort, Senecio jacobaea. Ecological Applications 3:682-698. 
[NARSC] National Applied Resource Sciences CenTER. 1996. Sampling vegetation attributes. Interagency Technical Reference BLM/RS/ST96/002+ 1730 .

[NCDC] National Climatic Data Center. 2004. Climate data by meteorological station. Available from: http: //www.ncdc.noaa.gov

Noy-Meir, I. 1985. Desert ecosystem structure and function. Pages 93-103 in M. Evanari and I. Noy-Meir, editors, Ecosystems of the world 12A: hot deserts and arid shrublands. Elsevier, New York.

Paul, E.A., And F.E. Clark. 1996. Soil microbiology and biochemistry. 2nd edition. Academic Press, New York.

PEART, D.R. 1989. Species interactions in a successional grassland. III. Effects of canopy gaps, gopher mounds and grazing on colonization. Journal of Ecology $77: 267-289$.

PLATT, W.J. 1975. The colonization and formation of equilibrium plant species associations on badger disturbances in a tall-grass prairie. Ecological Monographs 45:285-305.

Reichman, O.J., J.H. Benedix, and T.R. Seastedt. 1993. Distinct animal-generated edge effects in a tallgrass prairie community. Ecology 74:1281-1285.

Reichman, O.J., and E.W. Seabloom. 2002. The role of gophers as subterranean ecosystem engineers. Trends in Ecology and Evolution 17:44-49.

RickaRD, W.H., AND B.E. Vaughan. 1988. Plant community characteristics and responses. Pages 109-179 in W.H. Rickard, L.E. Rogers, B.E. Vaughan, and S.F. Liebetrau, editors, Shrub-steppe. Elsevier, New York.

Robertson, G.P., D.A. Wedin, P.M. Groffman, J.M. Blair, E.A. Holland, K.J. Nadelhoffer, and D. HARRIS. 1999. Soil carbon and nitrogen availability. Pages 258-271 in G.P. Robertson, D.C. Coleman, C.S. Bledsoe, and P. Sollins, editors, Standard soil methods for long-term ecological research, Oxford University Press, New York.

SAS Institute, Inc. 2004. SAS OnlineDoc. Version 9.1.3. SAS Institute, Inc., Cary, NC.

. 2005. The GLIMMIX Procedure, November 2005. SAS Institute, Inc., Cary, NC.

Schultz, J. 1995. The ecozones of the world. SpringerVerlag, New York.
Sherrod, S.K., and T.R. SEastedt. 2001. Effects of the northern pocket gopher (Thomomys talpoides) on alpine soil characteristics, Niwot Ridge, CO. Biogeochemistry 55:195-218.

Simkin, S.M., W.K. Michener, and R. Wyatt. 2004. Mound microclimate, nutrients and seedling survival. American Midland Naturalist 152:12-24.

SOJKA, R.E. 1999. Physical aspects of soils of disturbed ground. Pages 503-519 in L.R. Walker, editor, Ecosystems of the world 16: ecosystems of disturbed ground. Elsevier, New York.

Sollins, P., C. Glassman, E.A. Paul, C. Swanston, K. Lajtha, J.W. Heil, and E.T. Elliot. 1999. Soil carbon and nitrogen. Pages 89-105 in G.P. Robertson, D.C. Coleman, C.S. Bledsoe, and P. Sollins, editors, Standard soil methods for long-term ecological research. Oxford University Press, New York.

Spencer, S.R., G.N. Cameron, B.D. Eshelman, L.C. CoOper, AND L.R. Williams. 1985. Influence of pocket gopher mounds on a Texas coastal prairie. Oecologia 66:111-115.

Stanford, G., AND S.J. Smith. 1972. Nitrogen mineralization potentials of soils. Soil Science Society of America Proceedings 36:465-472.

UMBANHOWAR, C.E.J. 1995. Revegetation of earthen mounds along a topographic-productivity gradient in a northern mixed prairie. Journal of Vegetation Science 6:637-646.

UNGER, P.W., AND T.C. KASPAR. 1994. Soil compaction and root growth: a review. Agronomy Journal 86:759766.

Whitson, T.D., L.C. Burrill, S.A. Dewey, D.W. Cudney, B.E. Nelson, R.D. Lee, and R. Parker. 1999. Weeds of the West. 5th edition. Western Society of Weed Science, Jackson, WY.

Wolfe-Bellin, K.S., and K.A. Moloney. 2000. The effect of gopher mounds and fire on the spatial distribution and demography of a short-lived legume in tallgrass prairie. Canadian Journal of Botany 78: 1299-1308.

Received 12 January 2007 Accepted 17 March 2008 